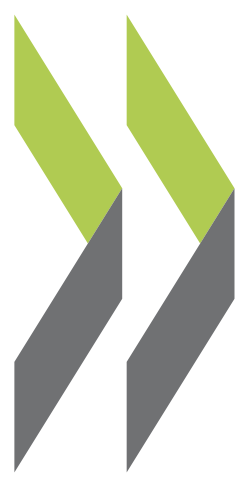

SIGMA Papers No. 27

\title{
European Principles for Public Administration
}

OECD 


\section{Unclassified}

Organisation de Coopération et de Développement Economiques

Organisation for Economic Co-operation and Development
CCNM/SIGMA/PUMA(99)44/REV1

OLIS : 19-Nov-1999

Dist. : 22-Nov-1999

SIGMA -- A JOINT INITIATIVE OF THE OECD AND THE EUROPEAN UNION,

Or. Eng.

PRINCIPALLY FINANCED BY THE EUROPEAN UNION'S PHARE PROGRAMME

\section{EUROPEAN PRINCIPLES FOR PUBLIC ADMINISTRATION}

SIGMA PAPERS: No. 27 
THE SIGMA PROGRAMME

SIGMA - Support for Improvement in Governance and Management in Central and Eastern European Countries is a joint initiative of the OECD and the European Union. The initiative supports public administration reform efforts in thirteen countries in transition, and is principally financed by the European Union's Phare Programme.

The Organisation for Economic Co-operation and Development is an intergovernmental organisation of 29 democracies with advanced market economies. Its Centre for Co-operation with Non-Members channels the Organisation's advice and assistance over a wide range of economic issues to reforming countries in Central and Eastern Europe and the former Soviet Union. Phare provides grant financing to support its partner countries in Central and Eastern Europe to the stage where they are ready to assume the obligations of membership of the European Union.

Phare and SIGMA serve the same countries: Albania, Bosnia-Herzegovina, Bulgaria, the Czech Republic, Estonia, the former Yugoslav Republic of Macedonia, Hungary, Latvia, Lithuania, Poland, Romania, Slovakia and Slovenia.

Established in 1992, SIGMA works within the OECD's Public Management Directorate, which provides information and expert analysis on public management to policy-makers and facilitates contact and exchange of experience amongst public sector managers. SIGMA offers beneficiary countries access to a network of experienced public administrators, comparative information, and technical knowledge connected with the Public Management Directorate.

SIGMA aims to:

- assist beneficiary countries in their search for good governance to improve administrative efficiency and promote adherence of public sector staff to democratic values, ethics and respect of the rule of law;

- help build up indigenous capacities at the central governmental level to face the challenges of internationalisation and of European Union integration plans; and

- support initiatives of the European Union and other donors to assist beneficiary countries in public administration reform and contribute to co-ordination of donor activities.

Throughout its work, the initiative places a high priority on facilitating co-operation among governments. This practice includes providing logistical support to the formation of networks of public administration practitioners in Central and Eastern Europe, and between these practitioners and their counterparts in other democracies.

SIGMA works in five technical areas: Public Administration Development Strategies; Policy-Making, Co-ordination and Regulation; Budgeting and Resource Allocation; Public Service Management; and Audit and Financial Control. In addition, an Information Services Unit disseminates published and on-line materials on public management topics.

\section{Copyright OECD, 1998}

Applications for permission to reproduce or translate all or part of this material should be made to: Head of Publications Service, OECD, 2 rue André-Pascal, 75775 Paris Cedex 16, France.

Views expressed in this publication do not necessarily represent official views of the Commission, OECD Member countries, or the central and eastern European countries participating in the Programme. 


\section{FOREWORD}

This paper attempts to identify the standards to which EU candidate countries are expected to conform in order to align their public administrations with those of EU Member States. Originating from SIGMA's work on public administration reform in central and eastern European countries, in particular civil service development and administrative control, the paper describes an important part of the basis of the SIGMA methodology for assessing candidate countries' public administration capacities.

An early version of this paper was reviewed at the first meeting of the Heads of Civil Services in the ten countries which are candidates for entry into the European Union, held in Vienna in November 1998. The meeting launched a SIGMA project aimed at assessing the countries' public administration capacities and in particular their progress in civil service development. Prior to publication, the final version of the paper was reviewed by participants in the $10^{\text {th }}$ SIGMA Liaison Group Meeting held in Prague on 15-16 November 1999.

Prepared by the SIGMA Secretariat, with Mr. Francisco Cardona, Advisor on Public Service Management, as its main author, the paper has also benefited from the input of independent experts. SIGMA wishes to thank Prof. Denis Galligan, Director of the Centre for Socio-Legal Studies at Wolfson College, University of Oxford, United Kingdom, Prof. Jacques Ziller of the Law Department at the European University Institute in Florence, Italy, Prof. Jürgen Schwarze, Director of the Institute of Public Law at Albert-Ludwigs University in Freiburg, Germany, and Mr. Jacques Fournier, former member of the Conseil d'Etat and current member of the Conseil supérieur de la Magistrature, France, for their valuable contributions. SIGMA would also like to express its appreciation to Dr. Helmut Kitschenberg, former Director of the Federal Academy of Public Administration, Germany, and to Dr. Wolfgang Rusch, Lecturer in Constitutional Law at the Institute for Public Administration in the State of North Rhine Westphalia, Germany, for their helpful comments.

The paper is published under the responsibility of the Secretary-General of the OECD.

SIGMA-OECD

2 rue André-Pascal, 75775 Paris Cedex 16, France

Tel. (33.1) 45.24.79.00; Fax (33.1) 45.24.13.00

e-mail: sigma.contact@oecd.org; http://www.oecd.org/puma/sigmaweb 


\section{TABLE OF CONTENTS}

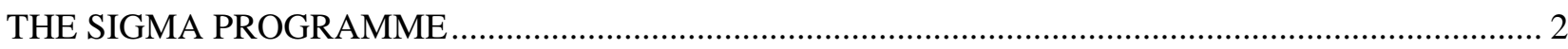

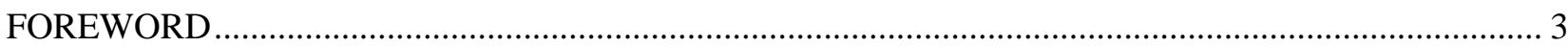

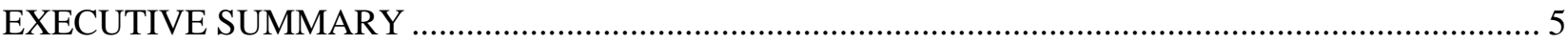

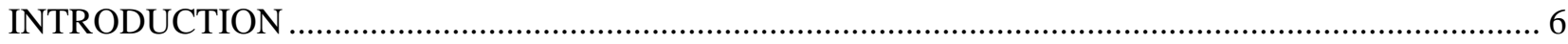

PART I. ADMINISTRATIVE LAW PRINCIPLES AND THE EUROPEAN ADMINISTRATIVE SPACE8

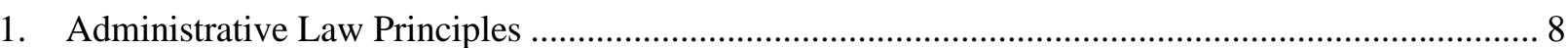

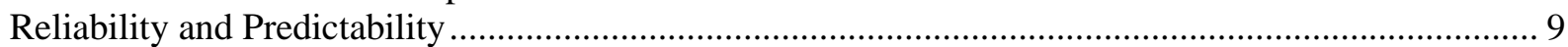

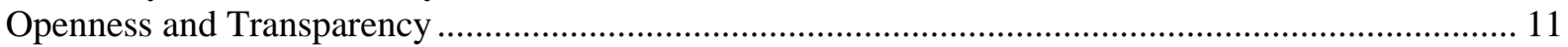

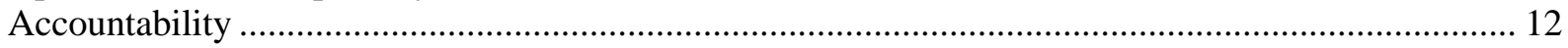

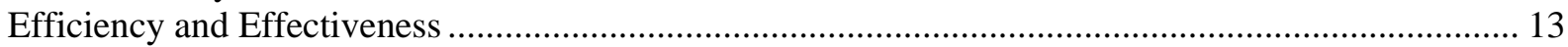

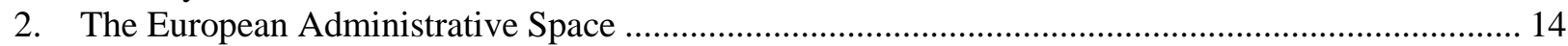

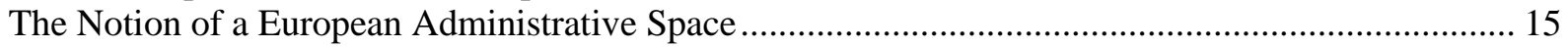

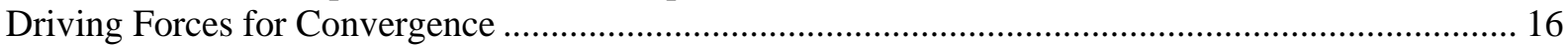

The Role of the European Court of Justice in the Emergence of a Common European Administrative

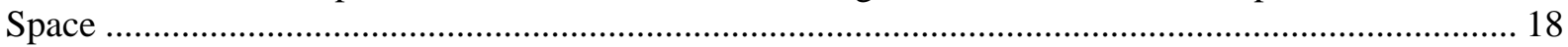

The Level of Convergence of Administrative Systems ................................................................. 18

PART II. ADMINISTRATIVE LAW PRINCIPLES AND CIVIL SERVICE STANDARDS .................... 20

1. Legal Structures for a Professional Civil Service: State Employees or Civil Servants?.................... 20 Similar Standards and Conditions, but Different Models of Professional Civil Service....................... 21

2. Managing the Civil Service in an "Administration Through Law" Context ..................................... 24

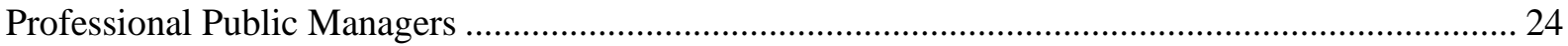

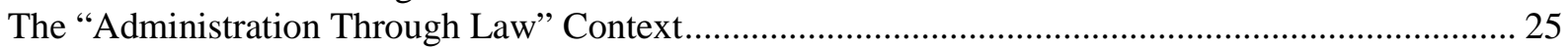

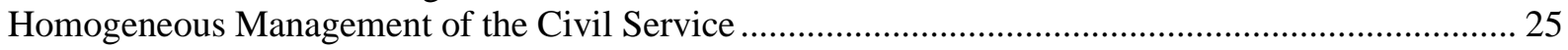

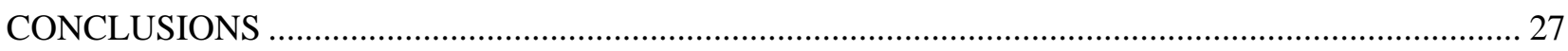

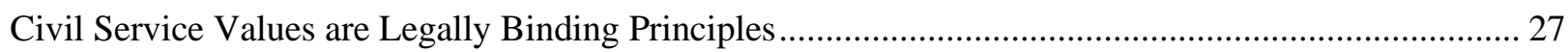

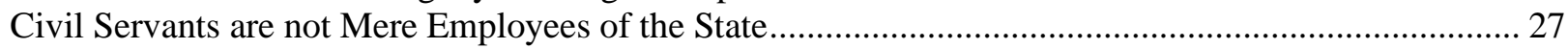

Administrative Law Principles Create Civil Service Behavioural Patterns ........................................... 28

Administrative Law Principles Contribute to the Creation of a European Administrative Space ............ 28 
CCNM/SIGMA/PUMA(99)44/REV1

\section{EXECUTIVE SUMMARY}

Central and eastern European countries applying for membership in the European Union need to reform their public administrations to meet the Copenhagen and Madrid criteria for accession. Most areas of government are covered or affected by the acquis communautaire (i.e. the entire body of legislation of the European Community). In the various domains of the acquis, targets and content of reforms are fairly clear. Candidate countries need to transpose EC legislation into the domestic legal order and then implement and enforce it. Difficulties and delays are mainly linked to the process and pace of implementation due to a lack of capacity.

No acquis communautaire exists for setting standards of horizontal systems of governance or national public administrations. Targets and orientations for public administration reform in the perspective of EU accession are therefore less distinct. However, over time a general consensus on key components of good governance has emerged among democratic states. These components include the rule of law principles of reliability, predictability, accountability and transparency, but also technical and managerial competence, organisational capacity and citizens' participation. Despite the lack of an acquis communautaire, this consensus has established principles for public administration shared by EU Member States with different legal traditions and different systems of governance. Over the course of time these principles have been defined and refined through the jurisprudence of national courts and, subsequently, the jurisprudence of the European Court of Justice.

Shared principles of public administration among EU Member States constitute the conditions of a "European Administrative Space" (EAS). The EAS includes a set of common standards for action within public administration which are defined by law and enforced in practice through procedures and accountability mechanisms. Countries applying for EU membership should take these standards into account when developing their public administrations. Although the EAS does not constitute an agreed part of the acquis communautaire, it should nevertheless serve to guide public administration reforms in candidate countries. In EU Member States these standards, together with principles established by the constitution, are usually embedded in or transmitted by a set of administrative laws, such as administrative procedures acts, administrative process acts, freedom of information acts and civil service laws.

The extent to which a given candidate country shares these public administration principles and adheres to the standards of the EAS gives an indication of the capacity of its national public administration to effectively implement the acquis communautaire, in accordance with the criteria made explicit by the European Council in Copenhagen and Madrid. It is within this context that the paper formulates its general conclusion.

In the second part of the paper, the civil service is situated within this broader context. This part of the paper aims to provide a better understanding of the links between the performance and management of civil servants on the one hand and the general principles of good governance and administrative standards constituting the EAS on the other. Among the conclusions drawn is the conviction that civil servants are not mere employees of the state but also have a constitutional role. It is therefore inappropriate to regulate the relationship between the state or a state institution and its civil servants entirely by labour law. 


\section{INTRODUCTION}

Membership in the European Union requires that every administrative domain and industrial sector of a Member State respects the acquis communautaire. For example, if the national dairy industry in a candidate country is to survive beyond the day of accession, it has to meet all of the requirements of the acquis. If not, the industry will not be able to export its products to other Member States. In fact, it will not even be able to trade within its own domestic market.

The national public administration institutions of EU Member States implement and enforce the acquis communautaire. To be able to effectively do the same, the public administration of a candidate country must adhere to the general principles of good governance and meet the administrative standards defined within the EU. Implementation of the acquis in an administrative domain is of course a matter of capacity and resources within the relevant sector - but not only that. The general horizontal governance systems of a candidate country must also meet the requirements of the EU, since they are crucial for the reliable functioning of the entire administration, including the areas of the acquis. Successful implementation and enforcement is clearly dependent on horizontal governance structures and systems, such as procedures for administrative actions and mechanisms to ensure that the performance of civil servants is in line with EU standards.

The lack of general EC legislation applicable in the domains of public administration and administrative law poses a problem for candidate countries. Candidate countries are required to have administrative systems and public administration institutions capable of transposing, implementing and enforcing the acquis according to the principle of "obligatory results" ("obligation de résultat"). Candidate countries have to meet the criteria required for EU Membership as adopted by the European Council in Copenhagen, Madrid and Luxembourg. In addition, candidate countries' progress will be measured against those criteria, i.e. in the wording of the European Commission's Regular Reports, in terms of their "administrative and judicial capacity to apply the acquis", which signifies implicitly that their progress will be assessed against European administrative standards.

It is in this context that this paper describes the European Administrative Space (EAS) as a specific part of EC law. The EAS is a metaphor with practical implications for Member States and embodying, inter alia, administrative law principles as a set of criteria to be applied by candidate countries in their efforts to attain the administrative capacity required for EU Membership. The EAS represents an evolving process of increasing convergence between national administrative legal orders and administrative practices of Member States. This convergence is influenced by several driving forces, such as economic pressures from individuals and firms, regular and continuous contacts between public officials of Member States and, finally and especially, the jurisprudence of the European Court of Justice. 
Although constitutions and subsequent legislation convey general law principles and define standards for administrative actions, it is the courts that refine those standards, i.e. define levels of acceptability for public administration practices on a case-by-case basis. Traditionally, standards of administrative performance have been defined and refined within the national boundaries of sovereign states. They have been the products of national constitutional arrangements, law-making activity of national parliaments, decisions of national administrative authorities and rulings of national courts. Within the EU this process is becoming increasingly supranational, and, for the reason of membership, it is possible to require shared mandatory administrative standards, as defined by the European Court of Justice at the European level and thus across Member States.

However, stressing the harmonising potential of public administration standards is not to say that administrative institutions should be homogeneously set up across EU Member States. The important message is that, independently of institutional arrangements, national public administrations must recognise principles and adhere to standards that are shared by EU Member States.

This paper describes administrative law principles defined by the European Court of Justice which in fact set public administration standards. Its purpose is threefold: firstly, it aims to define and provide criteria to give direction to public administration reforms in candidate countries; secondly, it provides benchmarks against which progress could be assessed; thirdly, the ultimate purpose of the paper is to assist candidate countries in meeting the Copenhagen and Madrid public administration criteria for EU accession. 


\section{PART I. ADMINISTRATIVE LAW PRINCIPLES AND THE EUROPEAN ADMINISTRATIVE SPACE}

\section{Administrative Law Principles}

Although the expression and concepts of administrative law (Verwaltungsrecht, droit administratif) differ from one national system to another, it is possible to agree upon a common definition of administrative law as being the set of principles and rules applying to the organisation and management of public administration and to the relations between administration and citizens ${ }^{1}$.

The administrative law principles, setting standards and inspiring the behaviour of civil servants, usually appear scattered among different pieces of legislation ranking from the constitution to several acts of Parliament, and specific pieces of delegated legislation as well as case law of the courts dealing with litigation concerning public administration. This is the case, among others, for countries such as Belgium, France, Greece, Ireland, and the United Kingdom. Other countries have put in force general codification on administrative procedures, which gather and attempt to systematise many of these principles. This is the case for Austria (since 1925) Bulgaria (1979), Denmark (1985), Germany (1976), Hungary (1957), the Netherlands (1994), Poland (1960), Portugal (1991) and Spain (1958).

These administrative principles are not simply ideas based on goodwill; they are embedded in institutions and administrative procedures at all levels. Actors in the public sphere are legally obliged to comply with these legal principles, which must be upheld by independent control bodies, systems of justice and judicial enforcement, parliamentary scrutiny, and by ensuring opportunities for hearing and redress to individuals and legal persons.

In the field of European Community Law, the European Court of Justice has defined a large number of administrative law principles by making reference to the general legal principles of administrative law common to the Member States, in an ongoing process. Particularly important principles set forth in the jurisprudence of the European Court of Justice, which all Member countries must in turn apply domestically when applying EC Law, are, among others: the principle of administration through law; the principles of proportionality, legal certainty, protection of legitimate expectations, non-discrimination, the right to a hearing in administrative decision-making procedures, interim relief, fair conditions for access of individuals to administrative courts, non-contractual liability of the public administration ${ }^{2}$.

If we attempt to systematise the main administrative law principles common to western European countries, we could distinguish the following groups: 1) reliability and predictability (legal certainty); 2 ) openness and transparency; 3) accountability and 4) efficiency and effectiveness.

1. See J. Ziller, Administrations comparées: les systèmes politico-administratifs de l'Europe des Douze, Montchrestien, Paris, 1993. See also J. Schwarze, Europäisches Verwaltungsrecht, Nomos, Baden-Baden, 1988.

2. See J. Schwarze, Europäisches Verwaltungsrecht, Nomos, Baden-Baden, 1988. English version: European Administrative Law, London, 1992. 
Other principles can be derived from these ${ }^{3}$.

Administrative law principles and civil service are at times difficult to define. Frequently they seem to contradict each other in a given situation. Efficiency seems to be at odds with due process; professional loyalty to the government seems to oppose professional integrity and political neutrality; discretionary decisions might seem to go against the rule of law, and so forth.

This elusive nature of administrative law principles is one of the reasons why "blank concepts" are so common in administrative law and civil service regulations. This is also one of the reasons why national courts, and the European Court of Justice as well, are so often invoked to solve conflicts and to continually refine these definitions in a doctrinal construction, adapted over time.

Perhaps it is useless, and even counterproductive at times, to aim to clearly define the boundaries of administrative law principles. In terms of law-making, when such an attempt has been made, usually in the form of very detailed casuistic distinctions, the end result has frequently been more confusion. Confusion in this domain easily generates injustice. Exacerbated attempts to ensure detail in regulating such elusive matters tend to result in inconsistency and contradiction. Contradiction and discrepancy also cause difficulties in making these principles actual by adversely affecting law enforcement. From the perspective of law making it is probably wise to resort to "blank concepts" because of their malleability to fit in disparate situations. From the standpoint of civil servants' and public authorities' behaviour, relying on common sense and seeking inspiration from consolidated case law doctrine would be advisable.

\section{Reliability and Predictability}

A number of administrative law principles and mechanisms work in favour of the reliability and predictability, also termed as legal certainty or juridical security, of public administration's actions and decisions. All of these principles attempt to eradicate arbitrariness in the conduct of public affairs.

The rule of law (Rechtsstaat, État de droit) is a multi-sided mechanism for reliability and predictability. It assumes the principle of "administration through law". In essence, the rule of law means that public administration ought to discharge its responsibilities according to law. Public authorities make their decisions by following general rules or principles applied impartially to anyone who comes within their ambit of application. The stress is on the neutrality and generality of such application (principle of non-discrimination). Public administration should decide according to the rule laid down, and to the interpretative criteria produced by the courts, disregarding any other consideration. The rule of law opposes arbitrary power, cronyism and other deviations. The rule of law necessitates a strict hierarchy of legal rules enforced by independent courts as well as the principle that a public authority, normally, is not

3. See SIGMA Papers, No. 26, Sustainable Institutions for European Union Membership, OECD, Paris, 1998, p. 10.

4. Legal doctrine defines "blank concepts" as frequently elusive concepts containing broad, or even vague, principles to be filled and refined on a case-by-case basis by the courts, and by those other public authorities applying legislation. This elusiveness provokes numerous legal disputes that are submitted to courts, which have to match their own previous definitions with societal values and perceptions evolving in the course of time. Therefore, the conceptual contours of such principles remain permanently unclear. Blank concepts are, for instance, those of good faith, reasonableness, common good, loyalty. Virtually all legal principles can be deemed as blank concepts. Despite their elusiveness, blank concepts are extremely important for law-making and for law enforcement. 
vested with the power to contradict the general rules laid down and made public in a specific regulatory decision 5 .

A related application of the rule of law is the notion of legal competence. Public authorities can only decide on matters for which they have legal jurisdiction. Competency within this context means an expressly and legally bestowed power to decide on a given matter or issue of public interest, which legally enables the public authority not only to take decisions on the matter but also obligates it to take responsibility. A competent public authority cannot abdicate this responsibility. In this sense jurisdiction (or competency) is equal to responsibility. The notion of competency is strictly applied so that a decision made by an authority without legal jurisdiction is void and will be declared void by the courts.

Reliability and predictability of public administration are not necessarily at odds with administrative discretion (freies Ermessen, pouvoir discrétionnaire). Discretion and arbitrariness are not the same thing. Discretionary decisions refer to matters where, within a legal framework, some degree of choice is left to the decision-maker. Discretionary powers are conferred on administrative bodies for a number of reasons. Discretion does not mean unlawfulness. Discretionary decisions are necessary as the law cannot foresee every circumstance that may arise in future situations. Public authorities may be expressly allowed by the law to make discretionary decisions. Courts have elaborated a legal doctrine of administrative discretion, which contains various principles governing and constraining the exercise of discretion. Among these principles are those compelling the administration to act in good faith, to pursue the public interest in a reasonable way, to follow fair procedures, to uphold the requirement of equal treatment, and to respect the notion of proportionality. In other words, lawful discretion cannot operate without general administrative law principles, as they form a sort of counterbalance vis à vis the discretionary powers attributed to the public administration ${ }^{6}$.

Another principle acting in favour of reliability and predictability is the legal principle of proportionality. This means that administrative action should be proportionate to the end pursued by the law, without depriving citizens of more than is strictly necessary for achieving that end. Proportionality is likened to reasonableness. It also means that it is against the law to apply the law strictly when, by doing so, an outcome unintended by the law may appear. This can constitute abuse of administrative powers. Proportionality is particularly relevant in cases of compulsory purchasing orders (or expropriations) through which individuals are deprived of propriety rights for the sake of the public interest. The notion of proportionality has been particularly developed by the European Court of Justice following the lines already established in German law, and it has entered a majority of European administrative law systems through the channel of EC law?

One principle acting in favour of "administration through law" is the principle of procedural fairness ${ }^{8}$. This means procedures safeguarding accurate and impartial application of the law, and attention to social values, such as respect for persons and protection of their dignity. One concrete application of procedural fairness is the legal principle that nobody will be affected in his rights and interests without having been

5. Prééminence des actes réglementaires sur les actes individuels d'une même autorité publique, as it is expressed in French. This doctrine is considered of a French origin.

6. See European Court of Justice, Case Technische Universität München, 1991, ECR-I-5469.

7. See J. Ziller, "Le principe de proportionnalité en droit administratif et droit communautaire", in Actualité juridique, droit administratif, numéro spécial, juin 1996, pp. 185-188.

8. This principle is well recognised in European Community law. See for further details J. Schwarze, "The Procedural Guarantees in the Recent Case Law of the European Court of Justice", in Essays in Honour of Henry G. Schermers, Vol. II, Dordrecht, Boston, London, 1994, p. 487 ff. 
acquainted with the facts and issues at stake and heard in a suitable procedure. Giving notice of administrative action to interested parties is also intrinsic to fairness.

Timeliness in the action of public administration strongly supports the principles of predictability and reliability. Delay of public administration in making decisions and taking action can cause frustration, injustice or severe harm for both the public interest and for private interests. Delay can result from inadequate resources or lack of political resolve. But often it is associated with inefficiency and incompetence of civil servants. Legal rules can help to alleviate the problem by setting out clear time limits within which things must be done. On the other hand, a civil service with a recruitment scheme based on merit, and regularly providing training, can reduce incompetence within public administration, and works for the value of reliability.

Professionalism and professional integrity in the civil service clearly buttress the notions of reliability and predictability of public administration. Professional integrity of civil service relies upon the notions of impartiality and professional independence. Impartiality refers to the absence of bias. Within the public administration domain, bias means having an inclination in favour of a particular outcome in assessing a given situation, causing as a consequence an unjustified or unfair detriment to the general interest or to the right of other interested parties. It often has the stronger sense of prejudice or judgement for the wrong reasons. Legal provisions prohibiting civil servants from getting involved in decisions affecting matters in which they may have a personal or vested interest are intended to reinforce the value of impartiality.

Loss of professional independence suggests an official who is not exercising independence of thought and judgement, so as to block proper consideration of the case on its merits. Bribery, duress, uncontrolled political ambition, and intemperate desire for promotion are frequent causes for the loss of independence. Bribery results in loss of independence for unlawful profit. Duress generates loss of independence out of fear. Political ambition or professional greed can lead civil servants to succumb to flattery, and to blindly comply with the desires of their superiors or even unduly restrain their own judgement in advance.

A civil service whose recruitment and promotion system is chiefly based on political patronage or cronyism is more likely to hamper professional integrity than a system based on merit. A civil service system where civil servants have a specific statute regulating their right to career advancement, setting up clearly their rights and duties, providing a fair and proportionate level of wage income openly disclosed and well-regulated, and sound disciplinary provisions, makes civil servants less vulnerable to corruption, coercion and flattery and, as a consequence, contributes decisively to the value of professional integrity. As said above, professional integrity works in favour of reliability and predictability of public administration. Nevertheless, it must be said that the civil service's independence does not mean an absolute right to free judgement or opinion. There are professional standards to be observed and legal rules to comply with. It is necessary to strike a balance between the value of independence and that of loyalty to the lawfully ruling government.

\section{Openness and Transparency}

Openness suggests that the administration is available for outside scrutiny, while transparency suggests that, when examined closely, it can be "seen through" for the purpose of scrutiny and supervision. Openness and transparency allow, on the one hand, anyone affected by an administrative action to know its basis, and on the other, they render outside scrutiny of administrative action by supervisory institutions easier. Openness and transparency are also necessary instruments for the rule of law, equality before the law, and accountability. 
As a general rule, the conduct of public administration should be transparent and open. Only exceptionally should matters be kept secret or confidential, such as those truly affecting the national security or similar issues. Likewise, personal data should not be disclosed to third parties.

In reality, only a few specific issues affect national security. However, public authorities tend to declare matters as confidential more frequently than it is really necessary. It is worthwhile to mention here that, with the exception of Sweden since the end of the eighteenth century, the traditional standard of public administration was discreteness and secrecy. Only since the 1960s has the value of open government developed in other democracies, and it is nowadays considered as a particularly important standard for public administration. Previously, the only application of the principle of openness in the majority of Western democracies was, on the one hand, the principle that legal regulations could only enter into force once published in an official bulletin or journal, and on the other, that administrative decisions could only be applicable once they had been officially and duly forwarded to and received by those concerned.

Openness and transparency in public administration serve two specific purposes. On the one hand, they protect the public interest as they reduce the likelihood of maladministration ${ }^{9}$ and corruption. On the other hand, they are essential for protecting individual rights, as they provide the reasons for the administrative decision, and consequently help the interested party to exercise the right to redress through appeal.

Several practical applications of these principles exist in administrative law. Administrative actions have to be motivated and subscribed to by the appropriate competent authority. Public registers have to be made accessible to the general public. The agents of authority usually have to identify themselves to the public. Civil servants must accept certain restrictions to earnings from private activities, which have to be disclosed and authorised beforehand in any event. Particularly important to the application of openness is the obligation of public authorities to provide reasons for their decisions.

An administrative act or decision should be accompanied by a statement of reasons. This statement provides the reasoning followed by the public authority in shaping its decision and shows in particular the consistency between the facts and how these facts fit into the ambit of the legislation. Consequently, the statement of reasons should include the facts and evidence for them, as well as the legal justification applied. The statement of reasons is of utmost importance when an application from an interested party is being rejected. In this case, the statement of reasons should carefully show and justify why the argument or evidence submitted by a party has not been accepted.

What constitutes adequate reasons is always a difficult question in administrative law, which is often submitted to the courts for resolution. The important point, however, is that the statement of reasons must convey the grounds and a sufficient degree of justification to enable the interested party to prepare an appeal against the administrative decision. Providing the motive for administrative decisions is an instrument for openness, transparency and accountability.

\section{Accountability}

Generally, accountability means that one person or authority has to explain and justify its actions to another. So in administrative law it means that any administrative body should be answerable for its actions to other administrative, legislative or judicial authorities. Accountability also requires that no authority should be exempt from scrutiny or review by others. It can be effected through many different mechanisms, including review by the courts, appeal to a superior administrative body, investigation by an ombudsman, inspection by a special board or commission, and scrutiny by a parliamentary committee,

9. Within the European Union, the European Ombudsman is supposed to counteract maladministration. 
among many others. Accountability is instrumental in showing whether principles like the rule of law, openness, transparency, impartiality, and equality before the law are respected. Accountability is essential to ensure values such as efficiency, effectiveness, reliability, and predictability of public administration.

A particular characteristic of accountability in the domain of administrative law is that it is ensured through a complex array of quite formal procedures. There is not an abstract accountability but very concrete and legally defined matters to account for, through a set of very specific procedures. Not surprisingly, the matters to account for have chiefly to do with how well the principles embedded in administrative law are honoured by civil servants and public authorities on the one hand, and on the other, about how well the legal procedures for shaping public administration decisions are followed.

Supervision is needed to make public administration accountable, to ensure that administrative bodies use their powers properly according to law and follow established procedures. Institutions and mechanisms of supervision monitor and scrutinise the actions of public officials. The purposes of supervision are to assess whether public bodies are performing their functions effectively, efficiently and on time, and that the principles and procedures laid down, by either specific or general regulations, are upheld. In other words, supervision aims to ensure the administrative principle of "administration through law", as it is essential to protect both the public interest and the rights of individuals as well.

These supervisory institutions and mechanisms may take various forms: courts, prosecutor, ombudsman, internal and external audit, inspectorates, standard-setting authorities, parliamentary committees, the media, etc.

In short, all of these mechanisms and institutions are aimed at effectively enhancing the rule of law, transparency, accountability, effectiveness and efficiency as key principles in public administration and civil service. In other words, they are aimed at protecting individual rights as well as the public interest, at improving quality in decision-making and, finally, at enhancing reliability, legal security, and legitimacy of public administration.

No other contemporary social body or institution has so many and such various means of supervision and control as public administration has. This fact gives an idea of the particular and delicate role that the civil service is called upon to play in modern democratic societies.

\section{Efficiency and Effectiveness}

One specific dimension of accountability relates to efficiency in the performance of public administration. The recognition of efficiency as an important value for public administration and civil service is relatively recent. Insofar as the state has become the producer of public services, the notion of productivity has entered the public administration. Today, because of fiscal constraints in many States, the efficient and effective performance of public administration in delivering public services to the society is increasingly studied. Efficiency is characteristically a managerial value consisting in essence of maintaining a good ratio between resources employed and results attained.

A related value is effectiveness, which basically consists of ensuring that the performance of public administration is successful in achieving the goals and solving the public problems set for it by law and government. It mainly calls for analysing and evaluating the public policies in place, and for assessing how well they are being implemented by public administration and civil servants.

In recent Western European constitutions, such as the Spanish one (1978), efficiency and effectiveness of public administration have been enshrined as constitutional principles, along with more classical principles, such as the rule of law, transparency and impartiality. Likewise, administrative law often refers 
to economy, efficiency and effectiveness (known as "the three E's"), along with the rule of law, as the principles that must preside over public administration and civil servants' activities and decisions.

Efficiency as a managerial value might seem to conflict with the rule of law and due procedure as a political/democratic value. Public managers often see legal procedures as restrictions inimical to efficiency. Following established procedures may go against an economic use of means, and can adversely affect the ratio between costs and outcomes of an administrative action.

This conflict raises a large number of issues. A number of institutional and legal solutions attempt to address this contradiction. Among the institutional ones can be cited the process of transferring production activities towards the private sector via contracting-out, keeping for public administration the role of policy-making and monitoring the contract. Legally, the enactment of a wide and complex series of laws on public procurement has developed as part of administrative law. The EC directive on public procurement has proved to be an important source of homogenisation of legal principles throughout the EU.

European Community law also calls for efficient administration ${ }^{10}$, particularly with regard to the application of Community directives and regulations. This has obliged several Member countries to modify some of their domestic organisational and administrative structures and decision-making arrangements in order to be able to efficiently and effectively enforce European legislation and, in general, to ensure effective co-operation with Community institutions, as discussed in the next section.

\section{The European Administrative Space}

The principles enumerated above can be found in administrative law across all European countries. Although public administrations in European States are old structures, they have continuously adapted to modern conditions including EU Membership, which is itself evolving. Constant contact amongst public servants of Member States and the Commission, the requirement to develop and implement the acquis communautaire at equivalent standards of reliability across the Union, the emergence of a Europe-wide system of administrative justice, and shared basic public administration values and principles, have led to some convergence amongst national administrations. This has been described as the "European Administrative Space"11.

It is the purpose of this section to explore the forces driving towards this common European administrative space, how it is being created, what are the public administration standards established by a set of common administrative law principles, and, finally, how these standards should be present in any institution-building endeavour undertaken in countries seeking full membership of the European Union.

Legal systems of EU Member States are undergoing a process of constant approximation in many different fields under the influence of Community law, i.e., through the legislative activity of Community institutions and through case law of the European Court of Justice. Community law concepts are introduced into national systems by means of directly applicable regulations or of directives, which first have to be transposed into national law. Regulations and directives both have a direct impact on Member States' administrative systems and can lead to important changes in the legal principles applicable to public administration in a given specific policy sector.

10. See European Court of Justice, Case 68/81, Commission v. Belgium (1982), ECR 153.

11. See SIGMA Papers, No. 23, Preparing Public Administrations for the European Administrative Space, OECD, Paris, 1998. 
The case law of the European Court of Justice can establish principles of a more general nature, which are applicable in more than just a single substantive field of law. Furthermore, in many cases it is the interpretation of relevant EC law provisions by the European Court that leads to modifications in the way principles of administrative law are understood within a Member State ${ }^{12}$.

This allows us to record a sort of Europeanisation of administrative law as an outstanding element of recent legal developments.

All of this demonstrates the emergence of a European Administrative Space, which mainly concerns basic institutional arrangements, processes, common administrative standards and civil service values. This list is far from complete, and there are significant quality differences amongst the Members. Indeed, the problems raised by these differences amongst Member States is one of the main reasons why institution-building has been given such a high priority in the enlargement process towards Central and Eastern Europe. Candidate countries will need to develop their administrations to reach the level of reliability of the European Administrative Space and an acceptable threshold of shared principles, procedures and administrative structural arrangements. There is a minimum standard of quality and reliability of public administration that candidate countries should attain.

Also to be considered is the fact that EU integration is an evolutive process (principle of progression in the construction of the EU). This means that a country should show a sufficient degree of progress to satisfactorily compare itself with the average level of EU Member States. The level of convergence in 1986 (when Portugal and Spain joined the EU) changed in 1995 (when Austria, Finland and Sweden joined the Union), and it will again be different in the future, when candidate countries join the European Union. This means that it is not sufficient for candidate countries to reach the current average level of public administrations in existing EU Member States. It will be necessary for them to reach the future average level of Member States. In other words, a candidate country should be able to fill the gap between the current level of quality of its public administration and its level in the future, when it has to effectively join the Union. It will be not enough for a candidate country to compare itself with the "worst" State which is already a Member of the Union. The comparison has to be established between the candidate country and the average of all Member States.

\section{The Notion of a European Administrative Space}

The notion of a European administrative space is taken from the more common notions of European economic and social spaces, widely debated upon in EU constitutional negotiations. It also relates to an EU-wide system of judicial co-operation, which includes mutual assistance in law enforcement and some approximation in the relevant field of law.

A common administrative space, properly speaking, is possible when a set of administrative principles, rules, and regulations are uniformly enforced in a given territory covered by a national constitution. Traditionally, the territory where administrative law has been applicable has been that of the sovereign states. The issue of a common administrative law for all the sovereign states integrated into the European Union has been a matter for debate, unevenly intensive, since the outset of the European Community. No common agreement yet exists.

12. See J. Schwarze (ed.), Administrative Law under European Influence: On the Convergence of the Administrative Laws of the EU Member States, Nomos, Baden-Baden, and Sweet and Maxwell, London, 1996. 
It is obvious that the main constitutional legal texts of the European Union, namely the Treaty of Rome (1957) and the Maastricht Treaty (1992), do not provide a model of public administration to be implemented by EU Member countries. Once the democratic nature of their political regime has been assessed, matters of governance and public administration are purposely left to the discretion of Member countries. Thus from a formal legal standpoint, Member countries have a great deal of administrative autonomy.

So far only certain elements of an eventual European administrative law have been laid down in the basic Treaties of the European Union and in the secondary legislation issued by the Commission. Important administrative law principles are stated in the Treaty of Rome, such as the right to judicial review of administrative decisions issued by EC institutions (article 173) or the obligation to give reasons for EC administrative decisions (article 190). However, only a few horizontal administrative issues have been the subject of legislative activity by European institutions. These matters have to do mainly with issues related to public procurement, ensuring the free competition of firms on EU territory and enabling them to bid in tenders called for in whichever EU Member country, and with issues related to state aid to enterprises, which have to be authorised and closely monitored by European Union institutions.

On the contrary, there is a very large amount of legislation regarding substantive, sectoral administrative law provisions, which constitutes what is known as the acquis communautaire. When a Member State fails to implement EC law contained in directives and regulations, there is an important legal consequence. The State is deemed as liable for non-contractual responsibility, through its unlawful failure to transpose an EC directive or to apply an EC regulation. This provides sufficient grounds for an individual to sue the state in court for compensation of damages ${ }^{13}$.

The absence of a formal legal body regulating public administration, its procedural rules, and its institutional arrangements does not mean that European supranational administrative law is meaningless or unknown to EU Member States. There exists a common acquis made up of administrative law principles, which could be referred to as a "non-formalised acquis communautaire" in the sense that there is no formal convention. It could, however, represent a common European general administrative law.

\section{Driving Forces for Convergence}

The European Communities, which initially involved mainly the creation of a common economic market, have evolved towards a European Union, which is not only driven by economic interests, but increasingly by the desire of building closer social and political ties among the people of Europe, as was intended by the signatories of the Rome Treaty. The European Union no longer means simply a common market of goods and services.

The four liberties embedded in the Treaty of Rome, i.e. free movement of goods, services, people, and capital, mean that national public administrations of the Member States, as key elements for ensuring and implementing that freedom, directly derived from the Treaties, have to work in a way that renders effective the implementation of those Treaties in all their respects. The EC Treaties and the European Commission's secondary legislation for implementing them are part of the domestic legal order in Member States. National public administrations and national courts are committed to apply the Treaties, and the secondary legislation issued by the Commission as "the guardian of the Treaties", with the same care as if they were genuinely domestic.

13. See the European Court of Justice's ruling in joined cases C-6/90 and C-9/90 "A. Francovich et al. v. Italy", 1991. 
The result is that, although each Member State has total liberty to decide on the ways and means of achieving the results predicated by the Treaties and EC secondary legislation, shared means and principles have developed within the Union. This situation is particularly visible in the field of administrative law principles. It is less visible, however, in the field of administrative and organisational arrangements and structures because of the great variety in forms and depth of decentralisation within the different Member States.

The legislative activity of the European institutions is thus a major source of common European substantive administrative law governing EU Member states, their public administrations, their courts, and their citizens. This substantive administrative law has the characteristic of being mainly sectoral. It somewhat affects a varied assortment of policy domains, such as free competition within the internal market, telecommunications, environment, agriculture, industrial policy, science and research, border controls, and so forth. This substantive administrative law constitutes the acquis communautaire, whose level of compatibility with those corresponding regulations of the applicant countries is now being screened and assessed by the European Commission within the framework of the accession negotiation process.

Another source of administrative approximation is the constant interaction among officials of Member States and between the latter and those of the European Commission. These intergovernmental relations, which are mainly relations between people, contribute to fostering a common understanding of how to implement EU policies and regulations at national levels and a fruitful exchange on best practices for achieving the results these policies are meant to attain. Inter-administrative co-operation is also one of the concepts fostered and reinforced by the Maastricht Treaty (article 209A). Co-operation and exchange have the effect of creating informal peer pressure for setting shared standards for the way in which national public administrations meet their supranational commitments, and of ensuring the attainment of the policy results foreseen in the basic Treaties and secondary legislation of the EC. These intergovernmental relations contribute to spreading and sharing a set of common administrative principles and ways of management, which in turn helps to pattern a shared ideal role model for the behaviour of civil servants throughout the Union. The mentioned effects of such intergovernmental relations are possible, to a great extent, because the officials involved are able to develop a rather stable professional career within their own national civil services.

However, it is the European Court of Justice which plays, by and large, the major role in shaping common administrative law principles within the European Union. Whereas the EC secondary legislation is almost exclusively sectoral, the rulings of the European Court of Justice lead to reflections on, and development of, administrative principles which are more general in nature, even if they are set forth on a case-by-case basis. In fact, the jurisprudence of the Court is the main source of general, i.e. non-sectoral, administrative law in the Union. The Court needs to rely on already established, general administrative law principles which have been created and refined by national administrative courts of EU Member States. The Court, by taking stock of these national case laws, defines and refines general administrative principles binding on all Member States as such, and on their citizens, in the application of EC law.

Finally, a phenomenon of pervasiveness of EC law into national legal orders has been noted ${ }^{14}$. This phenomenon is generated by the fact that it would be very difficult to use, within a given State, different standards and practices for applying national law and EC law. Progressively, national institutions are applying the same standards and using the same practices for applying both national and EC law. This fact

14. See J. Schwarze (ed.), Administrative Law under European Influence: On the Convergence of the Administrative Laws of the EU Member States, Nomos, Baden-Baden, and Sweet and Maxwell, London, 1996. See also G. Marcou, Les mutations du droit de l'administration en Europe: pluralisme et convergences, L'Harmattan, Paris, 1995. 
is leading to the idea of common administrative law being developed amongst the EU Member States. This sort of "contamination" of national laws by EC law principles is also contributing to the establishment of a European Administrative Space.

\section{The Role of the European Court of Justice in the Emergence of a Common European Administrative Space}

As already mentioned, it is the European Court of Justice which has elaborated most of the administrative law principles governing what could be termed as common European administrative law. This is only natural because of the fragmented nature of European administrative written law. The Treaties were designed to serve as a framework requiring further and continuous developments. Many issues were designated for regulation by the Commission's secondary legislation (directives and regulations), which covers mainly sectoral policy fields, and by case law submitted to the European Court of Justice.

National courts of justice are called upon to ensure the implementation of the EU Treaties and the Commission's secondary legislation. As EC law has to be interpreted in a uniform manner, national courts are induced, when the wording of a piece of legislation could appear to be unclear, to refer the issue to the European Court of Justice for interpretation (art. 177, EC Treaty). This has contributed to the prominent role which the European Court plays in developing common principles, by setting an interpretative framework to be followed by national courts. It can be said that today there is a common acquis of legal administrative principles developed by the European Court of Justice.

Administrative law principles have been discussed in the previous section of this paper. In summary, we have identified the main legal administrative principles, modelled after national administrative laws of EU Member countries by the European Court of Justice.

In the early years, the European Court of Justice case law was influenced by the legal systems of the initial Member States, and particularly by concepts stemming from French administrative law. Yet there has never been a sole French influence on the development of EC law, and the growth of Membership has led to a diversification of the sources of inspiration of the European Court of Justice's legal thinking. This means that the rulings of the Court do not respond particularly to a given national legal background, but that its jurisprudence is rather a composite of influences stemming from virtually all Members of the Union $^{15}$. For example, the "administration through law" principle originated in the French principe de légalité as well as in the German concept of Rechtsstaatlichkeit, which are more or less close to the British concept of the rule of law. It is worth noting that even though these three notions have different national roots, they are nowadays conducive to similar practical effects ${ }^{16}$. The concept of "fair procedure" can be traced back to British and German legal traditions.

\section{The Level of Convergence of Administrative Systems}

A given administrative system can be assessed by scrutinising the extent to which these principles are actually applied, both in the formal legal arrangements in a country, and also in the daily behaviour of public authorities and civil servants. In this sense, these general administrative law principles serve as standards against which to measure the reliability of the public administration, the degree of accountability

15. See J. Schwarze, European Administrative Law, op.cit.

16. See J. Rivero, "Vers un droit européen : nouvelles perspectives en droit administratif", in M. Capelletti (ed.), New perspectives for a Common Law in Europe, Publications of the European University Institute, Vol. 1, Florence, 1978, p. 389 ff. 
of civil servants and public authorities, the soundness and practicability of procedures for shaping administrative decisions and for challenging them through appeal and redress.

The extent to which different countries share these administrative law principles also gives an orientation as to the degree of compatibility amongst their administrative systems. In other words, they also serve as preconditions for a closer integration among them on the one hand, and on the other, as measurements of the capacity of public administration institutional arrangements in a given country to implement the formalised acquis communautaire.

One of the main elements composing public administration, among others such as appropriate substantive and procedural laws, is the civil service. The behaviour of the civil service is patterned after those administrative law principles as guiding and binding principles. Substantive and procedural administrative laws, shaped against the backdrop of national constitutions and European administrative law, provide the legal institutional framework within which public authorities and civil servants have to behave in Member countries of the EU.

At the same time all of these elements, legal arrangements and behaviour of actors in the public sphere of European societies shape the emerging common European administrative and political space. Players in this field are supposed to take for granted a set of principles, which rarely appear formalised in written laws, nor systematised in a code, but which are ethically and legally binding, and which cross horizontally all public administration settings. These principles are what we call the non-formalised acquis communautaire. This non-formalised administrative acquis communautaire strongly contributes to cementing the emerging European administrative space, and to the Europeanisation of national public administrations and administrative law of EU Member States.

Our conclusions, which also form our working hypothesis, would be as follows: Firstly, the extent to which general administrative law principles inspire national legislation and are present in real behaviour of public actors, i.e. the level of implementation of the non-formalised acquis communautaire, is indicative of and correlates with the capability of a given country to effectively adopt and implement the formal acquis communautaire. Secondly, this calls for close attention to developments in national civil services, as they are decisive instruments for either ensuring or hindering the transfer of these administrative law principles into actual public actions and decision-making processes.

Regarding the scope of this paper, it is apparent that the actualisation, to an acceptable extent, of the administrative principles of reliability, predictability, accountability, transparency, efficiency, and effectiveness are required if central and eastern European candidate public administrations are to meet EU accession requirements, particularly those demanded by the real application of the acquis communautaire. These principles do not work on good intentions alone, but have to be embodied entirely in the daily behaviour of public administration by means of substantive legislation, appropriate administrative institutions, and a set of legal values embedded in the civil service. This requirement provides an additional reason for having a professional and stable civil service. Not only do the majority of EU Member countries have specific civil service regulations, but their civil services are also bound by the administrative law principles required for making their public administrations reliable. 


\section{PART II. ADMINISTRATIVE LAW PRINCIPLES AND CIVIL SERVICE STANDARDS}

\section{Legal Structures for a Professional Civil Service: State Employees or Civil Servants?}

The main role of the modern state in a democratic, market-based economy is to provide fair and equal conditions and standards as the basis for the daily life of individuals and for the economic activities of individuals and legal entities. The basic mechanism used by the state is law. Passing and enforcing acts of parliament, delegated legislation, and by-laws, monitoring their effects and providing mechanisms for correction and redress are important tasks of the modern state.

The first role of the state in the field of employment is therefore to regulate basic relations between employers and employees. The state has to set minimum standards in order to establish fair working conditions for all employees, as well as to define the minimum rights and obligations of the two parties in an employment relationship.

The state also has the role of employer. In this second role, as opposed to its first and general role, the state is responsible for ensuring the efficient, professional and impartial performance of the public administration. This management responsibility creates a need for specific regulations governing state employees: staffing and career management policies, and management systems for selection, recruitment, promotion, and remuneration, all of which aim to guarantee the homogeneous and high quality of the staff and its performance among all branches and levels of government.

Closely related to its role as employer, the state also has constitutional responsibilities in running the public administration in accordance with principles enshrined in the constitution and in administrative law. Furthermore, the state has to ensure the performance of the public administration in accordance with such basic legal principles.

The modern concept of public administration entails a notion of hierarchical delegation of state powers to individuals operating within the public system. These individuals, the civil servants, are therefore not merely employees of the state but also, to a great extent, holders of state powers. As such, they also have to ensure that constitutional and administrative law principles are actually applied in the daily operation of public administration.

Law usually regulates relationships between civil servants and the state. Even if some aspects of these relationships are regulated by individual or collective labour agreements, the parties involved in such agreements cannot get rid of constitutional and administrative law principles. Therefore, whatever the legal source regulating the relationships between the state and the civil servants, their content has to take into account a set of principles of administrative law, in the sense described above, and to impose them upon public officials. Modern constitutions contain provisions regarding the regulation of the civil service, or even set up general models of public administration. Most of these constitutions require a specific body of law to regulate the special relationships between civil servants and the state. For instance, the constitutions of France, Germany, Greece, Italy, Portugal, and Spain include, directly or indirectly, basic principles for the civil service. 


\section{Similar Standards and Conditions, but Different Models of Professional Civil Service}

Modern, constitutional civil service in a democracy ${ }^{17}$ is regarded as possible only when a set of conditions are in place:

- Separation between a public sphere and a private sphere.

- Separation between politics and administration.

- Development of individual accountability of civil servants by overcoming former collegial decision-making processes. This calls for well-educated and skilful public managers.

- Sufficient job protection, stability, and level of pay, and clearly defined rights and duties of civil servants.

- Recruitment and promotion based on merit.

All of these conditions contribute, to a great extent, to defining the nature and values of a modern professional civil service.

The distinction between public and private spheres is as old as the distinction between state and society. It entails the recognition that there is a domain where the public interest has to prevail and that this public interest has to be free from individual private interests' interference. It also implies that this public domain has to be regulated by specific legal principles, and that the actors performing within this public sphere are, as such, to be subject to these principles.

The separation between politics and administration involves the basic assumption that, within the public domain, there are two main parts, which although closely interdependent, are different in nature, have a different underlying logic, and have different sources of legitimacy. Politics is based on public confidence expressed in free political elections, and validated after each political term. Administration is based on merit and professional capability of civil servants is verified in open competition for entering the civil service, in accordance with the terms laid down by law.

The introduction of personal, individual accountability for the decisions made and actions undertaken implies the acknowledgement that responsibilities and competencies within public administration are clearly defined. The important notion of an administrative competent organ, and the fact that every administrative decision has a clearly defined-by-law public authority to account for, are developments of the notion of individual accountability.

The domain of the administration is served by civil servants (Beamte, fonctionnaires). In defining their civil services, EU Member countries have adopted different approaches, usually rooted in the history of their respective states and modified over time. A number of countries, such as France, Ireland, the Netherlands, Spain, and Sweden have civil services which encompass every public employee, as it is considered that every public employee is part of the executing machinery of the state (broad concept of civil service), whereas other countries, such as Austria, Germany, United Kingdom, and more recently, Denmark and Italy, have restricted the scope of the concept of civil service to the so-called "core public administration", basically meaning those functions that only the state has the legitimacy to carry out, according to a conventional common political understanding. In the latter case, only professionals of public management and administration, and professionals holding state powers (e.g. police, customs, etc.) are civil servants (restricted scope of the concept of civil service). Among central and eastern European

17. See Raadshelders and Rutgers, "The Evolution of Civil Service Systems", in Bekke, Perry and Toonen (eds.), Civil Service Sysems in Comparative Perspective, Indiana University Press, 1996. 
countries, Hungary, and Poland are applying this restricted concept of civil service, whereas Lithuania is envisaging to employ a modality of the broad concept.

When the concept has a rather narrow scope of application, civil servants are, at least, those entrusted with public authority and legal competencies to exercise public powers, and to propose public policies and regulatory instruments, or to give advice on them. Defined in this way, the civil service is a part of the power of the state, it is integrated within the public sphere, and it is shaped in accordance with constitutional and administrative law arrangements. In all EU Member countries, even in those where a restricted concept of civil service is used, some basic tenets of constitutional and administrative law have been extended to the non-civil servant state employees, such as the requirement of merit-based recruitment. This is aimed, inter alia, at enhancing the legitimacy of the public employment system as a whole.

Whichever the case, but particularly if a restricted concept is used, in order for the civil service to be able to carry out its tasks, a number of conditions have to be in place. The civil service has to be shaped as an institution requiring from its members a specific degree of professionalism and integrity, and a good knowledge of administrative and constitutional laws. Civil servants must be subject to a set of legal conditions, which enable them to effectively execute their functions and competencies, in a proper and lawful manner, across all public administration settings. These legal conditions are mainly related to rights and duties, professional stability, protection from political encroachment and from the interference of lobbies, adequate level of salary in order to reduce the likelihood of corruption, disciplinary provisions, and selection based on merit. Merit-based recruitment and promotion signifies selecting the best suitable candidates available for the civil service, and precluding patronage and cronyism in the staffing of public administration.

Enacting specific civil service regulations is the more commonly used way of creating those legal conditions for the civil service stated above, because the civil service, as holder of public powers, is a prominent actor within the public sphere. Therefore, it is usually considered as needing a specific Act of Parliament or, as in the United Kingdom, a specific form of regulation by the executive (Civil Service Order in Council).

As already stated, the state is responsible for a professional, impartial, and efficient public administration, abiding by the rule of law. This role is not only a regulatory one but also a managerial one. The state has to guarantee a certain quality of its staff and an equal quality of standards across all public administration settings. In this sense, a legally well-designed and managed civil service system enables the state to reach adequate standards of professionalism, stability, continuity, and quality of public service in all parts of its public administration. All of this also presupposes that the political level in a country is highly aware of the necessity of long-term investment in people able to run the public affairs in an appropriately professional manner. Professionalism cannot be dissociated from stability and long-term forecasting.

There are several reasons why state employees should not be considered as merely state workers. Servants of the state have to achieve a number of targets, which are different from those present in ordinary labour relationships. Among these targets, the following can be enumerated:

- To establish mechanisms of control and accountability in order to prevent abuse of public powers and mismanagement of public resources.

- To give legitimacy to the public administration in the eyes of citizens and taxpayers in order to build up public confidence in the administration, and in the end, in the state as a whole.

- To distinguish as far as possible a public domain of politics from a public domain of administration, as the underlying logic in each domain is different, and consequently, their sources of legitimacy are also different, as already explained above. 
- To provide professional continuity in public administration and to foster a certain pattern of conduct in all parts of the administration, rendering it predictable. To do so, the legal administrative principles described above in this paper play a key role.

- To attract the best available candidates in the country for the civil service and to retain them through a reasonable prospect of career development and personal self-fulfilment.

These objectives are essential for laws on civil service. An overview of the status quo in western European countries offers a vision of the solutions, i.e. different models, adopted to facilitate their attainment.

In a number of EU Member countries, most public employees have the status of civil servants. This means that they are governed by a civil service act and its secondary legislation, and not by the general labour laws establishing minimal standards for the contractual relationships between workers and employers in the private sector. This is the case of Belgium, France, Greece, Ireland, the Netherlands, Portugal, and Spain.

The United Kingdom is a particular case: civil servants have specific regulations conferring them the status of civil servants. Constitutional principles reserve the jurisdiction for this to the Cabinet (Royal Prerogative). This, inter alia, explains why there is no civil service act in this country.

In other countries, only a portion of permanent government employees has the status of civil servants. In Germany, there is a typical distinction between civil servants, who are those employees holding public authority or state powers (approximately $40 \%$ of public employees) and the rest, who are subject to the labour laws. The reason is that the German Constitution provides such a model, and the criterion upon which to draw the borderline between Beamte (civil servants) and Angestellte (state employees) is the fact of performing functions implying the exercise of public authority. Civil servants are regarded as the executing arms of the state, able to serve whatever government of the day (political neutrality principle), and accountable, for their performance, to the law. The concept of "exercise of public authority" is closely related to issues having to do with the national interest, law and order, sovereignty of the state, law enforcement, and so forth. However, the two highest levels of university professors are also civil servants, though with special statutes. Non-civil servants are regarded as simply performing a profession in the public sector of the economy, or within the public services funded by the state budget.

The German model, close to those of Austria and Luxembourg, was followed by Denmark some decades ago, and recently by Italy. In Italy a major reform took place in 1993 and now only a few thousand higher officials are under the scope of the civil service law, the remainder being subject to the labour code and collective labour agreements.

The criterion for the application of the EC Treaty provisions on the free movement of labour forces across EU Member States has also been the concept of public authority or safeguard of the general interests of the state or local government. Henceforth, jobs in the public sector must be open to any EU citizen in whichever EU Member State, with the only exception of those positions expressly reserved for nationals by domestic civil service regulations. These regulations comply with the European Court of Justice case law only if they follow that basic criterion. Roughly speaking, it is reckoned that 60 to 90 per cent of public service jobs in EU Member States are today open to citizens of all Member States, which means that only 10 to 40 per cent of the total jobs in public service are reserved for nationals. In other words, only 10 to 40 per cent of public positions have something to do with the "exercise of public law powers and safeguarding the general interest of the state", to use the wording of the European Court of Justice ${ }^{18}$.

18. European Court of Justice, Case 149/1979, Commission v. Belgium. 
Therefore, civil service regulations in Member countries are key references to enforce these EC law principles.

\section{Managing the Civil Service in an "Administration Through Law" Context}

\section{Professional Public Managers}

Western European countries have, for a long time now, recognised the fact that management standards and the performance of public managers are critical for the success of both the general performance of the public administration and public administration reform endeavours.

Improving the performance of the public administration means seeking better standards of efficiency and effectiveness within the rule of law. This usually requires delegation and devolution of responsibilities in favour of public managers, accompanied by ex ante and ex post control mechanisms. In such a situation, the quality of public managers, vested with these public powers, becomes of the utmost importance. Moreover, when national policy-making becomes more and more complex and more and more exposed to international co-ordination, as it is the case in all EU Member States, the need for top public managers, with broad perspectives and ability to co-ordinate their work with both national and international institutions, becomes even more apparent.

France, with its career system and its corps, has by tradition defined groups of senior officials. Individuals at the top of their career in each corps are centrally managed and assisted in career development through training and mobility. The state has a pool of competent individuals to select from when a top position is to be filled. Other countries are establishing similar defined groups of top managers who are centrally selected, appointed, trained and managed. The Netherlands, with its devolved administration, is developing a Senior Public Service with a strong emphasis on the professional development of managers and on improving co-ordination capacities. Although this kind of senior civil service does not yet exist in central and eastern European countries, some of these countries are gradually introducing special policies and management mechanisms for the highest officials in government. Hungary, Latvia and Poland are examples of countries that are currently implementing reforms related to top managers, although with very different approaches ${ }^{19}$.

In the previous central and eastern European administrative systems, there was no understanding of a common state administration profession. Each job within the state administration was regarded as a specialist job in the employing institution with limited career bridges to jobs in other institutions, and without clear professional criteria also valid for a job elsewhere in the state administration. Mobility between different institutions was not encouraged and was rare.

On the other hand, the fact that the co-ordination of policies, and between institutions, was done within the political party structure implied that there was no need for generalists or managers with a broader perspective than that of their own technical field. The kind of permanent management positions that can be found at higher levels within Western civil services was, and still is, in most central and eastern European countries, the prerogative of the political class. Non-politically selected managers were, and in many cases still are, competent specialists within their field of expertise, providing technical contributions but rarely ensuring management and co-ordination.

19. See SIGMA Papers, No. 1, Top Management Service in Central Government: Introducing a System for the Higher Civil Service in Central and Eastern European Countries, OECD, Paris, 1995. 
Civil service reforms in central and eastern European countries should also be aimed at establishing a public management profession within the civil service. This entails actions in several domains: training managers; introducing regulations defining duties, accountabilities, and corresponding rights of staff, as in a civil service specific regulation; improving personnel management and management standards; and, above all, establishing an administrative context in which officials and public managers can carry out their duties in a professional, impartial, transparent and controllable way.

\section{The "Administration Through Law" Context}

This administrative context is made up of several factors, the more important of which are:

- The quality of substantive regulatory law: Regulatory law provides the framework for decision-making within a given policy field (for instance, in urban planning or on environmental issues). In other words, it represents a tool for officials and a source of information and prediction for the public.

- The quality of procedural administrative law: Procedural administrative law provides due procedures for administrative decision-making, for co-ordination and for balancing powers, for officials' relations and communication with the public, and for enabling any interested party to be heard or to appeal.

- The quality of financial and administrative accountability and control mechanisms: These work for transparency, provide checks for financial and administrative decision-making, and provide means for correction, prosecution and redress.

At the same time, these three factors provide the legal values and principles which contribute decisively to shaping the attitude and behaviour of public managers and the rest of the civil servants operating within that administrative context. These legal principles will be essential as guiding principles for decision-making and behaviour; they will reduce the likelihood of arbitrary decisions by allowing discretionary decision-making within the legal administrative framework. In the end, the principles of administrative law will strongly contribute to laying the foundation of a professional public administration.

The professionalisation of the public administration is, therefore, a much wider task than implementing civil service regulations and introducing personnel management improvements. If the administrative context within which officials have to work is not also improved, they might still have to make arbitrary decisions, with insufficient communication with the public, and insufficient co-ordination with other institutions, even if they are in a situation where they have been selected on merit and are exposed to systematic training.

\section{Homogeneous Management of the Civil Service}

One problem inherited from past administrative structures in central and eastern European countries is the lack of co-ordination and the lack of common standards for personnel management across public administrations. This fragmentation should be mended and personnel management should be harmonised within the public administration to ensure that an acceptable level of common administrative law and civil service standards are attained and maintained.

To do so, a different notion of civil service should be taken into consideration. Civil service should be regarded as a common management function within the public administration. This common function is aimed at ensuring that principles of administrative law, such as those mentioned above, and basic legal 
conditions, such as merit-based recruitment and promotion, fair salary treatment, and equal rights and duties, are homogeneously disseminated, understood and upheld throughout the public administration as a whole. This common function calls for some kind of central capacity for the management of the civil service.

In a number of Western European countries, such as France, Portugal and Spain, a specific ministry of public administration or public service is in charge of the general aspects of civil service management. This usually consists of preparing draft acts and regulations for civil service, organising or monitoring recruitment, co-ordinating human resources management, negotiating with civil service unions on behalf of the government, and organising and managing general or specific training activities through purposeful bodies, such as schools or institutes of public administration.

In other countries, such as Austria, Belgium, Germany, Ireland and the Netherlands, the Ministry of Finance or the Ministry of Internal Affairs performs this role of managing the civil service.

In Italy and Sweden, a specific agency has been set up for negotiating with civil service unions on behalf of national government and agencies, and of local governments as well.

The responsibilities and the institutional character of such a capacity to manage the civil service should also be defined in a civil service act. It can be a unit preparing decisions for the Prime Minister or for the Council of Ministers. It can be a special ministry, or it can be a separate institution reporting to the Prime Minister. Many kinds of institutional arrangements are possible. The important thing is that this central capacity should be vested with sufficient powers to effectively manage horizontally across the public administration. 


\section{CONCLUSIONS}

This paper has attempted to be a reflection on how administrative law principles and civil service standards are intertwined. At the same time, it has aimed to show how standards and principles feature a set of common understanding, which is widespread in the emerging European administrative space, mainly by virtue of the European Court of Justice. Administrative law stems from constitutional arrangements that are deeply rooted in cultural, social and political values coalescing around the tenets of democracy. The civil service is one main element of public administration; but as it is such a major element, public administration and civil service are often considered to be synonymous.

This leads to three principal concluding remarks: firstly, civil service values are legally binding; secondly, regulating civil service goes beyond merely regulating the labour relationships between the state and its employees - it concerns regulating one of the state's powers in a broad sense. Thirdly, administrative law principles inspire the decision-making of public managers and pattern the behaviour of the civil service as a whole. Likewise, these principles constitute the benchmarks, or reference points, against which acceptable standards are set for the civil services and public administrations within EU Member States, as well as in EU institutions.

\section{Civil Service Values are Legally Binding Principles}

The civil service is bound by the principles enshrined both in constitutional arrangements and in administrative law. From this viewpoint, it can be said that civil service values are legal values. Legal values are not the same as ethical values, even if they can broadly overlap. Ethical values are guides for action, and their breaching deserves social reproach. Legal values, when breached, have legal consequences through the civil service law's disciplinary provisions. Civil servants are bound by the administrative principles established in legislation.

\section{Civil Servants are not Mere Employees of the State}

Civil servants are subject to legal principles and compulsory rules that derive from their specific location within the hierarchical structure of the state. This location shapes a profession, which deals with fundamental rights of their fellow citizens. Civil service regulations do not simply regulate the working relationships between an employer and its employees, as labour law does. Civil service regulations intend, on the one hand, to protect civil servants in performing their very special social role in democratic societies and, on the other, to tighten professional standards by virtue of the delicate issues which civil servants have to deal with. Civil servants are actors within the public sphere of society, the sphere which falls within the domain of public law.

Consequently, it is public law, and not ordinary labour law, that should regulate the delegation of power to take decisions on behalf of the state, the accountability of professional servants of the state, and the mechanisms for controlling the execution of public powers. This is therefore one basic reason for having a special civil service act as a part of administrative law. In contrast to working conditions, these matters cannot be defined on a contractual, individual basis. 


\section{Administrative Law Principles Create Civil Service Behavioural Patterns}

Nevertheless, a civil service system regulated by a civil service act is not sufficient to make a public administration professional, efficient, effective, impartial, abiding by the rule of law, and well-performing. It is also necessary to have substantive and procedural administrative legislation of sufficient quality. This legislation will not only provide civil servants with an important tool for performing their duties and for realising the public law principles described above, but also with clear procedures to guide their work and to render their actions and decisions predictable.

Additional procedural and substantive legislation is also needed to ensure sufficient internal and external control of public administration and the civil service, particularly in terms of public finance, quality control, procedural supervision, and above all, to ensure an independent, well-functioning judicial system able to effectively redress administrative actions and decisions by means of appeal. This requirement is not only for the sake of the legal certainty and reliability of public administration, but also to ensure the appropriate legal protection of individual rights and legitimate expectations.

\section{Administrative Law Principles Contribute to the Creation of a European Administrative Space}

In the end, the extent to which the entire administrative context, civil service included, in a given country meets commonly accepted standards, which are constructed upon and measured in relation to shared administrative law principles, will be of prime importance for candidate countries' attaining their EU accession goal or, in other words, for their becoming full players within the European Administrative Space. 